\title{
Conservation and Development in Amazonian Extractive Reserves: The Case of Alto Juruá
}

\begin{abstract}
Extractive reserves constitute an innovative approach to match conservation and development objectives, which were originally envisaged as part of a land struggle by forest dwellers in Brazil. In spite of the idea's popularity and the attempts to apply the concept to different tropical regions, there has been little analysis of the combined conservation and development performance of extractive reserve programs. We present a detailed analysis of deforestation and demographic and socioeconomic changes in Alto Juruá, the first extractive reserve created in Brazil in 1990. Forest cover has remained fairly stable. Population has declined slightly, with some internal displacements. The cash economy base has shifted from the original rubber production to a diversified portfolio of agriculture and livestock, and there has been a dramatic rise in nonagrarian income. We conclude that the Reserve represents a very dynamic setting with positive conservation and development outcomes during its first decade.
\end{abstract}

\section{INTRODUCTION}

Tropical deforestation has occupied a significant place on international conservation and environmental agendas for over two decades. During that period, around $15 \%$ of the world's tropical forests have disappeared $(1,2)$. The Amazon region, which hosts the largest tropical forests, has been a particular focus of this attention. Although still covered with huge expanses of forests, deforestation in Amazonia has been rife. By 2000, 57 million ha of the original 600 million ha of Amazonian forests had been destroyed. Brazil, with the largest extent of tropical forests in the world, has been at the heart of deforestation debates. Recent studies suggest for Brazilian Amazonia a yearly deforestation rate of 1.8 to 2.0 million ha during the period 1995-2000 $(3,4)$.

The causes behind Amazonian deforestation are multiple and complex, varying from region to region (5). However, a common element is the lack of concern for the populations living in the forests; these people have frequently been the victims of the different policies and processes at the root of this deforestation $(6,7)$. Thus, while conservation circles were directing their attention to Amazonian deforestation, those at the national and international levels concerned with human development were trying to bring forest people's interests to the forefront (8-10).

Both camps initiated a process of convergence in the mid1980 s as a result of internal and external events. Joint conservation and development reached the programmatic agendas of international organizations at the end of that decade, and particularly after the 1992 Rio Summit (11-13). In the case of Brazilian Amazonia, rubber tappers' organizations realized that typical forest-based extractive activities had a limited role in the economic debate about deforestation and land-use alternatives for the region. This prompted their leadership to seek support from other sources, adding an environmental component to their original land and social justice claims $(14,15)$. The concept of extractive reserves as a way to guarantee people's rights while preserving environmental values was born out of these conditions (16).

The December 1988 murder of Chico Mendes, the charismatic leader of the Brazilian National Council of Rubber Tappers, triggered massive international condemnation and paved the way for the Brazilian government to accept the establishment of extractive reserves $(6,17)$. The first extractive reserve was Alto Juruá, in the westernmost part of the Brazilian Amazon, created in January 1990. Since then, 16 reserves, with a total area of 3.4 million ha and a population of 28000 people, have been established, 12 in the Amazon region and 4 on the Atlantic coast. Another 3 are currently in the last phase before being declared, and 13 more have been proposed and are going through the legal process of establishment (Table 1).

Ever since their appearance, extractive reserves have been the focus of international attention. Their pros and cons have been discussed (19-23), and the suggestion of extending them to other tropical areas has been explored (24-26). However, very little empirical evidence is available to assess their actual outcome and to evaluate to what extent their stated conservation and development goals have been met. The purpose of this article is to report on the evolution of the forest and the human population of Alto Juruá (an area inhabited by rubber tappers and riverine agriculturalists), the first and one of the most emblematic extractive reserves, and to discuss the future prospects of this type of protected area.

\section{MATERIALS AND METHODS}

Alto Juruá lies on the border between Brazil and Peru (Fig. 1). The Extractive Reserve, created by decree 98863 on 23 January 1990, has an area of 506200 ha, and its current population is 4615 people (27). Administratively, it belongs to the Municipality of Marechal Thaumaturgo. The area is crossed by the Juruá River, a direct affluent of the Amazon, and has several secondary tributaries, notably the Tejo, Bage, and Amonia Rivers, that form an intricate river network. No roads or motorable tracks exist in the area; widespread foot tracks, together with the river network, constitute the only communication system.

The Alto Juruá Extractive Reserve (hereinafter called AJER) represents the first set of large, forest-based extractive reserves like the Chico Mendes, Cajarí, and Ouro Preto Reserves, created in the early 1990s. This group of reserves has large forest areas ( $>250000$ ha) very sparsely populated in dispersed

\begin{tabular}{|c|c|c|c|}
\hline Year & Number & Area $\left(\mathrm{km}^{2}\right)$ & Population \\
\hline 1990 & 4 & 21630 & 13912 \\
\hline 1992 & 9 & 22008 & 17862 \\
\hline 1997 & 11 & 25108 & 21562 \\
\hline 1998 & 12 & 31584 & 25562 \\
\hline 1999 & 13 & 32104 & 25962 \\
\hline 2000 & 16 & 34079 & 28992 \\
\hline \multicolumn{4}{|c|}{ Source: CNPT-IBAMA and Iglesias (18). } \\
\hline
\end{tabular}




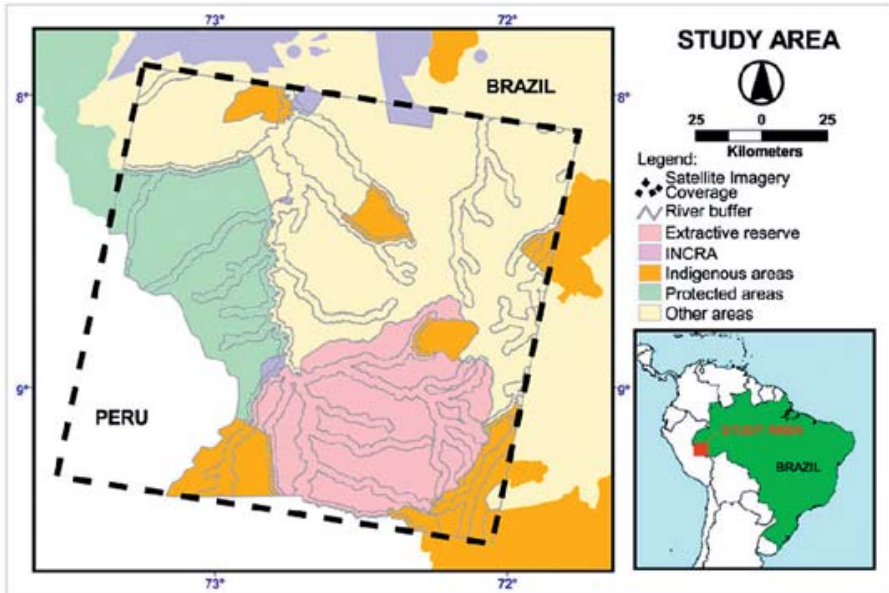

Figure 1. Map of Alto Juruá Extractive Reserve and its surrounding region. The dotted line indicates the area covered by the satellite image.

settlements. They share community organizational problems and a traditional, forest-based economy that has proven insufficient to match development expectations and that has thus evolved to incorporate other productive activities. At the same time, AJER has its own specificities, which include a rubber-based cash economy that was in crisis before other forest-based products and a high level of isolation that has sheltered it from surrounding pressures occurring in other extractive reserves, such as the Chico Mendes Reserve (28).

The AJER was first studied from an anthropological perspective by one of the authors in the mid-1980s (29). Since its creation, there have been two general censuses, one in 1991 (coordinated by one of the authors and funded by the Brazilian Environmental Institute, IBAMA) and one in 2000 (coordinated by CNPT, the institution in charge of extractive reserves and other traditional population areas). As part of an intense research program, a Brazilian multidisciplinary team with national and international support conducted two population and socioeconomic surveys based on different samples in 1995 $(\mathrm{n}=240)$ and in $1998(\mathrm{n}=74)$. The census and surveys have allowed to us to evaluate population and migration patterns, as well as changes in main economic activities, and to identify processes, trends, and expectations of the forest dwellers based on opinions expressed through different questionnaires. We have also used qualitative information and general trends detected in a survey $(n=82)$ conducted at the end of 2002 by one of the authors. Municipal censuses for 1991 and 2000 for West Acre (30) have been used to check regional-level demographic processes and to compare them with those occurring in AJER. That team also conducted ecological, geological, and soil surveys, as well as general reserve-level landcover studies based on remote-sensing techniques using Landsat TM images from 1989, 1992, and 1995.

We have revised the socioeconomic data from all censuses and have made new analyses of Landsat TM images from 1989 , 1992, 1995, and 1998 and of Landsat ETM images from 2000. All of them correspond to the month of August, facilitating the comparison through remote-sensing analysis of land-cover and deforestation processes. Given the importance of the river network in structuring population settlements and their associated activities, we differentiated three levels of river based on their width and, therefore, transportation capacity. A buffer of $3 \mathrm{~km}$ was used to differentiate between riverbank and hinterland areas.

All settlements in the reserve have been localized using global positioning system and incorporated into our GIS database in order to conduct a spatial migration analysis. Based on watersheds and riverbank-hinterland categorization, the whole reserve has been divided into eight main zones: the riverbanks of the four rivers mentioned earlier and their respective hinterlands. The images covered a much larger area than the reserve, thus allowing for a comparison between the reserve and its surrounding region, which includes seven Indigenous Lands, the large National Park of Serra do Divisor, and four sites of a rural development project supported by the Brazilian National Land Reform Institute (INCRA) that could be used as an alternative to compare different development scenarios.

\section{RESULTS AND DISCUSSION}

\section{(a) Forest-Cover Changes}

Forest-cover changes during the decade were calculated for AJER as well as for each of the gazetted zones defined earlier. Forest areas include secondary and mature forest as well as bamboo forests common in the region; deforested areas include bare land and grassland. Those areas covered with clouds in at least one of the satellite images were removed from the analysis. Net deforestation was calculated as the difference between the area that lost forest cover and the area that gained forest cover in the same period.

During the period 1989-2000, AJER continued to support a dense forest that covered $99 \%$ of the territory. Permanently deforested zones (bare land and grassland that remained such during the study period) represented only $0.35 \%$ of the area, with the rest being part of humanly induced successional changes between deforestation and reforestation normally linked to small-scale slash-and-burn agriculture practices. Given the very low population density, its concentration in the riverbanks, and the very small scale of their agricultural practices, most of the area is in fact mature or close to mature forest.

Deforestation in AJER increased during the first part of the 1990 s, because of population dynamics and economic changes (mostly a sharp fall in rubber prices) that took place when the reserve was first established (Fig. 2). Internal displacements and new economic activities flourished as a result of the opportunities opened by the creation of the reserve (see next sections). Since then, additional deforestation has been decreasing, and deforested areas seem to have reached a stable plateau at around $1 \%$.

However, there are marked differences in the extent of deforestation between hinterlands and riverbanks, the latter reaching $3.3 \%$ and $2.8 \%$ in the case of the Juruá and Amonia Rivers, respectively. It is worth mentioning that most of the deforestation in the hinterlands tends to be stable, whereas that on the riverbanks is marked by successional stages leading from forest clearance to secondary forest typical of small-scale slashand-burn systems.

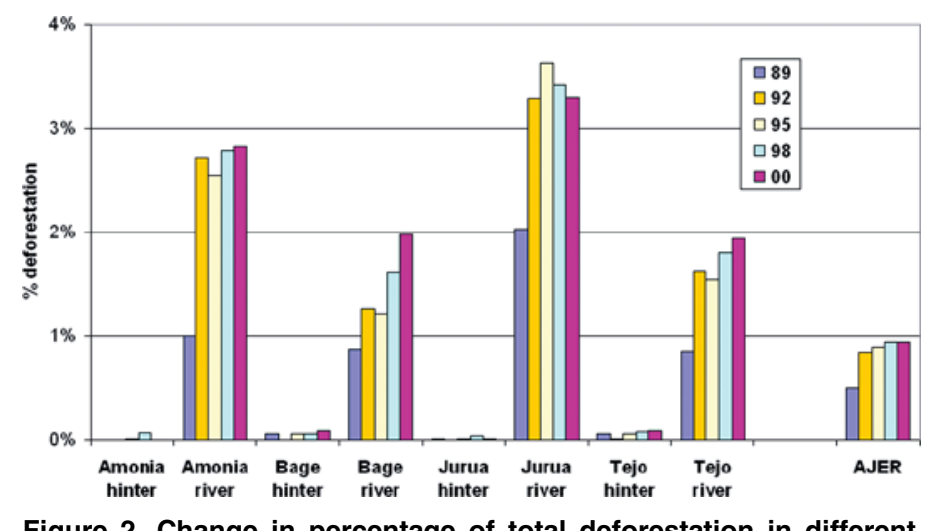

Figure 2. Change in percentage of total deforestation in different areas of Alto Juruá Extractive Reserve from 1989 to 2000. 
As in AJER, the rest of the surrounding region has also remained by and large under forest cover. However, we find two distinct patterns (Fig. 3). Areas gazetted as Indigenous Lands, the Serra do Divisor National Park, and AJER show lower deforestation levels (below 1\%). There is a trend toward stabilization at the end of the decade, best represented by an asymptotic trend model. Total deforestation in the four sites of the INCRA project, on the contrary, starting from the same low level as the other zones in 1989, reached $5.8 \%$ in 2000. In fact, total deforestation in the two sites close to AJER, where most of the INCRA development has taken place, reached $14.4 \%$ in 2000 , most of it having occurred since 1995. This process is best represented by an exponential growth trend model.

Some authors (31) have expressed concern over the use of forest cover as the only indication of forest conservation status. The studies undertaken in AJER and reported elsewhere (32) also show that the area has extremely high diversity of trees, birds, amphibians, fish, and butterflies. Moreover, because of the abandonment of the hinterland areas inside the reserve (see below), there are indications of the recovery of populations of some particularly threatened species, such as the jaguar (Panthera onca), the tapir (Tapirus terrestris), peccaries (Tayassu spp.), and several species of primates.

\section{(b) Demographic Changes}

Early 20th-century administrative reports of a number of rubber estates indicate that large areas of what is now the AJER were more densely populated than the surrounding zones (29). This was because of the abundance of naturally occurring rubber trees combined with a dense network of secondary and tertiary river tributaries that made the zone relatively accessible. However, the first complete and reliable censuses of the whole AJER were conducted only in 1991 and 2000, and these can be used to analyze demographic trends, in particular the ability to retain people, which could be considered an important indicator of the performance of AJER.

The comparison between the two censuses shows a $14.3 \%$ decline in the total number of people (5387 in 1991 versus 4615 in 2000) and a $10.0 \%$ decline in families (857 and 771 , respectively). In order to assess the significance of this decline, we try to compare demographic changes in AJER with those taking place in the region. During the 1990s Acre municipalities were restructured. This makes it difficult to use the municipal censuses of 1991 and 2000 to compare demographic trends in AJER with general trends in the region.

In order to overcome this limitation, current municipalities were regrouped into the four main municipalities of West Acre in 1991. The results are shown in Table 2, which also includes the same data for AJER.

Taken together, the population in West Acre increased by $28.9 \%$ over the decade. However, although the urban population grew by $57.6 \%$, the rural population grew by only $10.3 \%$, reinforcing the current urbanization trend in the region. In the case of Jordão and Tarauacá, two remote municipalities neighboring AJER, the rural population actually decreased by $13.3 \%$, a level comparable to the $14.3 \%$ decrease experienced by AJER, whose entire population is considered rural. Thus, the demographic trend in AJER during the 1990s resembles that of similarly isolated neighboring territories. The creation of the reserve does not seem to have changed the demographic pattern taking place in the most remote rural areas of West Acre.

It is worth mentioning the internal displacements occurring inside the reserve. An estimated 31\% of households have migrated from the settlement they occupied in 1991, of which 93\% stayed within the reserve displacements and 7\% migrated outside the reserve. The displacement has affected proportionally more of the young households, which often are established away from their family settlements. Likewise, the most common trend has been to abandon the hinterlands, moving to the more accessible and better-served settlements near the riverbanks, where riverine agriculture can be established.

An important aspect of the creation of AJER has been to offer people an opportunity to organize themselves in order to prepare the management plan, to allocate different responsibilities for the reserve governance, and to run all those activities that fall under its jurisdiction. The management plan, developed by the community and legally sanctioned by the Brazilian Environmental Institute IBAMA, is a fundamental component of the creation of the reserve. Its regulations include the maximum allowed total deforestation, provisions for specially
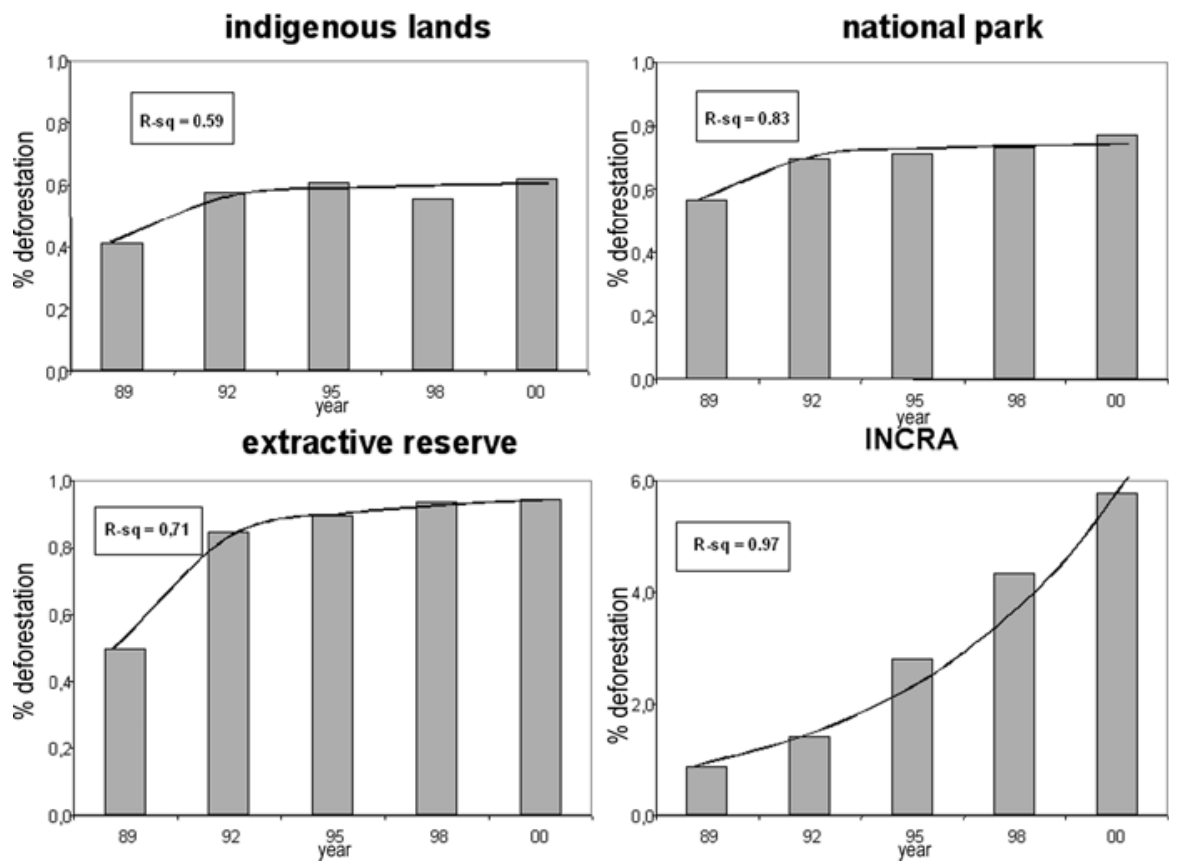

Figure 3. Comparison of deforestation trends in Alto Juruá Extractive Reserve and other areas in the surrounding region. The range of the scale for Indigenous Lands, National Park, and extractive reserve is $0 \%$ to $1 \%$. The range of the scale for INCRA development projects is $0 \%$ to $6 \%$. 
Table 2. Demographic changes in West Acre.

\begin{tabular}{|c|c|c|c|c|c|c|c|}
\hline Region & Municipalities & $\begin{array}{c}\text { Population } \\
1991\end{array}$ & $\begin{array}{c}\text { Percentage rural } \\
1991\end{array}$ & $\begin{array}{c}\text { Population } \\
2000\end{array}$ & $\begin{array}{l}\text { Percentage rural } \\
2000\end{array}$ & Area $\left(\mathbf{k m}^{2}\right)$ & $\begin{array}{l}\text { Rural population index } \\
\qquad(1991=100)\end{array}$ \\
\hline Juruá & $\begin{array}{l}\text { Cruzeiro do Sul + Thaumaturgo } \\
\text { + Porto Walter }\end{array}$ & 66603 & 58.2 & 81221 & 49.0 & 21668 & 103 \\
\hline Juruá & Máncio Lima + Rodrìgues Alves & 10217 & 65.0 & 19188 & 56.1 & 7977 & 162 \\
\hline Envira & Feijó & 17769 & 59.8 & 26722 & 57.9 & 22700 & 146 \\
\hline Tarauacá & Jordão + Tarauacá & 27659 & 65.4 & 30491 & 51.4 & 22815 & 87 \\
\hline Juruá & Alto Juruá Extractive Reserve & 5387 & 100 & 4615 & 100 & 5062 & 86 \\
\hline
\end{tabular}

protected areas in the reserve, the prohibition of commercial logging and hunting, as well as a ban on the use of explosives and poisons in fishing and dogs in hunting activities.

This process of political empowerment may be more important than the economic empowerment, as indicated in other extractive reserves in Brazil (33). According to the 2000 census, 90\% of AJER households are organized, mainly in the Alto Juruá Rubber Tappers and Farmers Association (ASAREAJ), whose services are used by $71 \%$ of respondents. The expressed desire to remain in the reserve is extremely high, with $97 \%$ of the respondents stating it. These results are very similar to those obtained in the survey conducted in 1998 with a sample of 74 households, of which only 5\% stated that they wanted to migrate elsewhere. This, combined with the fact that migration and displacements were more common in the first half of the 1990s, suggests that the reserve is an attractive option to the current population.

\section{(c) Economic Changes}

Like most extractive economies (34), AJER has a dual subsistence and market component. The subsistence part, centered around food production, home construction, and making a number of kinds of equipment, has changed little during the decade. Thus, most of the manioc, rice, maize, bananas, and acai produced in 2000 were consumed at home (Fig. 4). The subsistence component represents $65 \%$ of the total agroextractive production of the reserve, estimated at 780000 Brazilian Reais (USD1 $=1.83$ Reais in 2000) at current market prices. This is complemented by hunting and fishing, the products of which play a major role in the diet and are also consumed at home (see 32 for a discussion on subsistence hunting and fishing in AJER).

Rubber has been the main forest commodity produced in this region since the second part of the 19th century. The collapse of rubber prices, the changes in ownership of the seringais (rubber estates) and in traditional management practices by the new owners in the 1980s, as well as the emergence of rural trade unions are at the origin of the movement by rubber tappers and their associations to claim land rights, which eventually resulted in the creation of AJER in the aftermath of the murder of trade union leader and political organizer Chico Mendes. In 1990, rubber was still an important product in AJER, with 467 families $(54.5 \%$ of the total) producing 274.2 tons, with an average of $587 \mathrm{~kg}$ per rubber-producing family. In 2000 , only 161 families (20.9\% of the total) were still involved in producing 48.1 tons of rubber, or $299 \mathrm{~kg}$ per family. The 2002 survey indicates a slight increase in rubber production and number of families engaged due to recently introduced subsidies together with new processing technologies. Brazilian currency devaluation has increased the price of rubber paid in local currency, contributing to this slight increase.

Rubber has been mostly replaced by beans as the key commodity, with $67 \%$ of production sold, representing $38 \%$ of the total primary-sector cash income generated in the reserve in 2000 (Fig. 5). Beans are comparable with rubber in their ease of handling and transportation, although they are less durable than rubber, having some storage problems. The commodity has a prosperous market in town, acting as a de facto currency and unit of economic account in a region where paper money was until recently seldom exchanged, very much in the same way as rubber. However, unlike rubber, beans are a yearly crop that need open areas and tilled soils to grow. They are grown mainly on the riverbanks, taking advantage of the rivers' periodic floods and the consequent natural fertilization processes, which allow for a continuous growth of agricultural activities. This, together with better accessibility and availability of services, explains the intrareserve displacements, with resettlements near the rivers and abandonment of the hinterlands.

Another major change in the economy of the reserve has been the increase of livestock, which constitute $24 \%$ of the gross primary-sector production in AJER, representing the second largest source of income (Fig. 5). The trends for pigs and cattle, the two major components of livestock, are noticeably different (Table 3). The total number of pigs has increased markedly, and

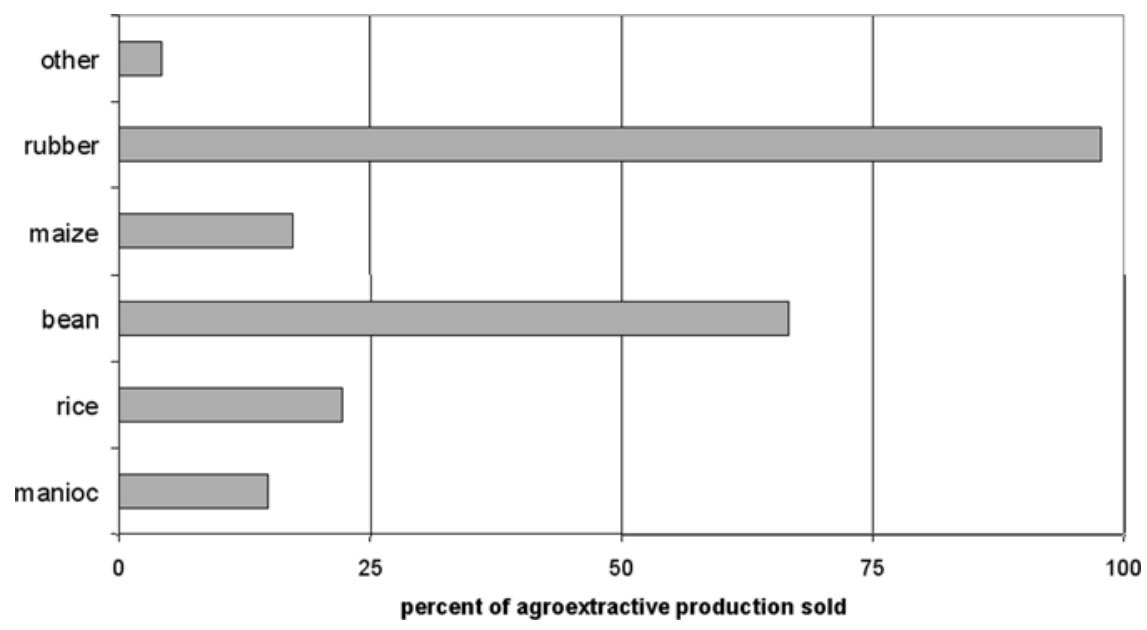

Figure 4. Percentage of total agro-extractive production sold. 


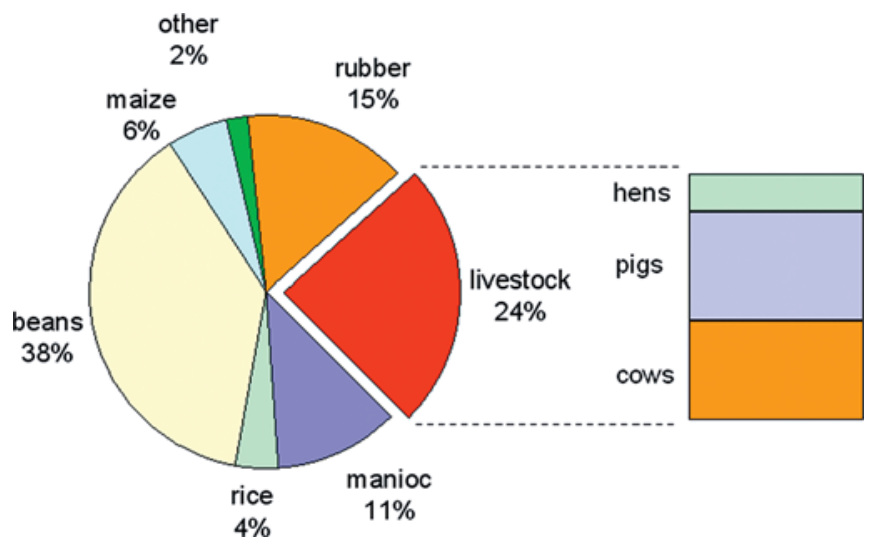

Figure 5. Structure of cash income from primary sector-based activities, with livestock income expanded in the bar.

this is mainly because of a substantial increase in the average number of pigs per family, rather than an increase in the number of families with pigs. Pigs are used both for home consumption and selling, the latter mainly sold among neighbors or in the local market. At the same time, the total number of cattle has increased more slowly, and this increase is mainly due to an increase in the number of families with cattle rather than the average size of the herd, which has remained fairly stable. The 2002 survey indicates an acceleration of this trend. Cattle are mainly sold to dealers who come from outside the reserve and take the cattle to the main urban areas in the region and elsewhere.

It is worth stressing at this point the persistence of a few large cattle owners, located mainly on the Juruá riverbanks. They correspond to old fazendas (large farms) inside the reserve, which were there already at the time of the creation of the reserve and have managed to accumulate herds of more than 50 cows, whereas most of the rubber tappers with cattle only own a few (35).

Finally, it is worth mentioning the importance of the cash income generated through non-primary-sector activities. Two main sources for this income are the microscale rubberprocessing units producing vegetal leather (36) and the income from salaries related to tertiary-sector activities (teachers, paramedics, and employees of the rubber tappers and farmers association ASAREAJ), together with pensions received by retired rubber tappers.

Census data on the number of people earning a salary are not currently available, but extrapolations of the 1995 and 1998 surveys to the whole reserve would result in an estimate of 125 people ( $16 \%$ of the total families) earning a salary. In order to estimate the total wage income, we calculated the current mean salary for a panel of six common wage activities in the reserve deflated to the year 2000 . This represents 2150 Reais per worker and year, or 268750 Reais of net wage income for the whole of AJER in 2000.

Likewise, a conservative extrapolation of the surveys to the total population would indicate that 190 people (representing around $25 \%$ of the households) benefit from a pension. Onefourth of those correspond to elderly rubber tappers who produced rubber during the Second World War and who were

\begin{tabular}{|c|c|c|c|}
\hline & 1990 & 2000 & Percentage change \\
\hline Number of pigs & 2345 & 4533 & 93.3 \\
\hline Families who own pigs & 336 & 397 & 18.2 \\
\hline Average pigs per family & 7.0 & 11.4 & 62.9 \\
\hline Number of cows & 1609 & 2559 & 59.0 \\
\hline Families who own cows & 211 & 319 & 51.2 \\
\hline Average cows per family & 7.6 & 8.0 & 5.3 \\
\hline
\end{tabular}

thus considered "rubber soldiers," with the right to earn a double pension. Estimated income from pensions would amount to a total of 392500 Reais $y^{-1}$. This is more than all the cash income from primary-sector activities, underscoring the growing importance of non-resource-based incomes for the cash economy of AJER. Moreover, in addition to their economic importance, pensions add a major social component, because they offer the elderly population their own source of income, thus contributing to the maintenance of their influence in the decisions being made at household as well as AJER-wide levels. This fact may help to explain the ability to put some control on more conventional development activities such as timber, livestock, and some cash crops, thus helping to maintain the positive environmental balance of AJER as a whole (37).

\section{CONCLUSION}

Any assessment of the establishment of AJER has to be placed in the context of offering viable livelihood options and conserving the forests. The reserve and its surrounding region are subject to dynamic processes that are resulting in environmental, demographic, and economic changes. In the first decade since the creation of AJER, there has been a marginal increase in permanent deforestation, whereas the temporary deforestation associated with slash-and-burn, smallscale agriculture has remained the same. However, during this period, there has been a spatial shift in the pressure on the forest. Thus, although the hinterlands have experienced a general process of reduced pressure and forest recovery, the riverbanks have seen more permanent and temporary deforestation.

In this sense, AJER has had a similar experience to that of the National Park of Serra do Divisor and the Indigenous Lands of the region, although AJER experienced higher deforestation rates when it was first created. They contrast with the exponential deforestation going on in the INCRA rural development projects. A development scenario based on the expansion of these projects to other zones within the region could trigger massive deforestation processes.

The population inside the reserve has declined, although this decline has been similar to that of isolated rural populations in the region. At the same time, there have been important intrareserve displacements, with population increase on the riverbanks and depopulation in the hinterlands. These migratory patterns reflect economic changes as well as the availability of services such as schooling or basic health and shopping facilities. Most population displacements took place in the first years of the creation of the reserve, when people tried to position themselves to take advantage of the new opportunities offered by its creation, including more secure land rights.

The combined effect of population decrease and higher deforestation at the early stages of AJER should send a warning signal. In fact, per capita deforestation between 1989 and 2000 has doubled, from 0.49 ha to 1.1 ha, although the process seems to have stabilized in the second part of the 1990s.

The AJER maintains a large self-sufficient component in its economy, with most food, housing, and several types of equipment coming directly from it. This subsistence part of the economy has a strong component of forest-based extractivism. The commercial part of the economy has shifted and no longer revolves around rubber. Two activities that were already present before the creation of AJER have grown in importance: beans as a key source of cash income and cattle as a source of cash and capital accumulation. These activities, particularly raising cattle, compete with forests and could create some potential conflicts between the stated aims of conserving forests and offering development opportunities to the people. More- 
over, pensions are growing in importance (and this will increase as the population ages), as are new employment opportunities around social services and other infrastructure created by the reserve. In this sense, the creation of AJER has undoubtedly contributed to diversifying sources of income and expanding their role in the economy of the area.

There is substantive evidence showing that people have a strong preference for staying in the reserve, and that a majority of them have joined the association created at the time of its establishment. These are clear social indicators of a positive effect of the reserve on people's opportunities, having offered them a chance to earn a secure livelihood and to participate in the management of the whole area. This political empowerment of rubber tappers has completed the process of transformation from proletarians to peasants described by Bakú (38) for the State of Acre.

Although the population living in the reserve has mobilized some resources to achieve this, most of the economic effort to maintain a stable organization and to mobilize the population has come from external sources, mainly the funding provided by the Brazil Pilot Program funded by the European Union and managed through the World Bank. This raises the important question of the long-term sustainability of the social organization, services, and infrastructure created with the reserve, which have been fundamental to its achievements. Recent programs introduced by the Brazilian government in support of the reserve are being considered as payment for the environmental services provided. The current trend is for such programs to be considered as permanent public expenditure to replace externally funded special projects, thereby internalizing the costs associated with conservation-oriented community management of this type of forest.

The AJER will continue evolving under its own dynamic, influenced by possible external support, by national policies, as well as by the development path of Acre and Brazil as a whole. In the meantime, we can say, with the reservations already mentioned, that the creation of AJER has been reasonably able to match the conservation, social, and development targets envisioned by those who proposed its creation, supporting conservation policies in the Brazilian Amazonia $(39,40)$.

\section{References and Notes}

1. FAO 2001. Forest Resources Assessment 2000. FAO, Rome, Italy, 479 pp

2. Matthews, E. 2001. Understanding the FRA 2000. World Resources Institute Forest Briefing No. 1. WRI, Washington, DC

Instituto Nacional de Pesquisas Espaciais (INPE) 2002. Monitoring of the Brazilian Amazonian Forest by Satellite, 2000-2001. INPE, São José dos Campos, S.P., Brazil.

4. Laurance, W.F., Albernaz, A.K.M. and da Costa, C. 2001. Is deforestation accelerating in the Brazilian Amazon? Environ. Conserv. 28, 305-311.

Southgate, D. 1998. Tropical Forest Conservation: An Economic Assessment of the Alternatives in Latin America. Oxford University Press, New York, 190 pp.

6. Hecht, S. and Cockburn, A. 1989. The Fate of the Forest: Developers, Destroyers and Defenders of the Amazon. Verso, New York, 266 pp.

7. Painter, M. and Durham, W.H. (eds.). 1995. The Social Causes of Environmental Destruction in Latin America. The University of Michigan Press, Ann Arbor, 288 pp. Destruction in Latin America. The University of Michigan Press, Ann Arbor,
WCED 1987. Our Common Future. Oxford University Press, Oxford, 398 pp.

9. Schwartzman, S. 1989. Extractive reserves: the rubber tappers' strategy for sustainable use of the Amazon Rainforest. In: Fragile Lands of Latin America: Strategies for Sustainable Development. Browder, J. (ed.). Westview Press, Boulder, CO, pp. 151-163.

0. Allegretti, M.H. 1990. Extractive reserves: an alternative for reconciling development and environmental conservation in Amazonia. In: Alternatives for Deforestation: Steps Toward Sustainable Use of the Amazon Rain Forest. Anderson, A. (ed.). Columbia University Press, New York, pp. 252-264.

11. Redford, K.H. and Padoch, C. (eds.). 1992. Conservation of Neotropical Forests: Working from Traditional Resource Use. Columbia University Press, New York, 475 pp.

12. Ghai, D. and Vivian, J.M. 1992. Grassroots Environmental Action: People's Participation in Sustainable Development. Routledge, London, $351 \mathrm{pp}$.

3. McNeely, J.A. (ed.). 1995. Expanding Partnerships in Conservation. IUCN and Island Press, Washington, DC, $302 \mathrm{pp}$

4. Mendes, F. 1992. Peasants speak: Chico Mendes - the defense of life. J. Peasant Stud. $20,160-176$.

5. Carneiro da Cunha, M. and Almeida, M.W.B. 2000. Indigenous people, traditional people, and conservation in the Amazon. Daedalus/J. Am. Acad. Arts Sci. 129, 315-338.

16. Allegretti, M.H 1989. Extractive reserves: a proposal for Amazonian forest development (In Portuguese). São Paulo Persa. 3, 23-29.

17. Almeida, M.W B. 2002. The politics of Amazonian conservation: the struggles of rubber tappers. J. Latin Am. Anthropol. 7, 170-219.

18. Iglesias, M.P. 1998. Socio-economic Survey, Biological Assessment and Land Tenure in the Area Designated for the Creation of Alto Tarauacá Extractive Reserve-Jordão e Tarauacá Municipalities, State of Acre (In Portuguese). 4 volumes. Rio Branco, Brazil.
19. May, P.H. 1989. The dilemmas of privatization: distributional effects of changes in extractive resources land rights (In Portuguese). Rev. Econ. Soc. Rural-Brasilia 27, 367389.

20. Fearnside, P. 1989. Extractive reserves in Brazilian Amazonian: an opportunity to maintain tropical rain forest under sustainable use. BioScience 39, 387-393.

21. Afsah, S. 1992. Extractive Reserves: Economic Environmental Issues and Marketing Strategies for Non-timber Forest Products. Draft Report. World Bank, Washington, DC

22. Browder, J.O. 1992. Social and economic constraints on the development of marketoriented extractive reserves in Amazon rain forests. Adv. Econ. Bot. 9, 33-41.

23. Pendelton, L.H. 1992. Trouble in Paradise: practical obstacle to non-timber forestry in Latin America. In: Sustainable Harvest and Marketing of Rain Forest Products. Plotkin, M. and Famolare, L. (eds.). Conservation International-Island Press, Washington, DC, pp. 252-262.

24. Peluso, N.L 1992. The political ecology of extraction and extractive reserves in East Kalimantan, Indonesia. Dev. Change 23, 49-74.

25. Ruiz Pérez, M., Sayer, J.A. and Cohen Jehoram, S. (eds.). 1993. Extractivism in Latin America (In Spanish). IUCN, Gland, Switzerland, $99 \mathrm{pp}$.

26. Salafsky, N., Dugelby, B.L. and Terborgh, J.W. 1993. Can extractive reserves save the rainforest? An ecological and socioeconomic comparison of nontimber forest products extraction systems in Petén, Guatemala, and West Kalimantan, Indonesia. Conserv. Biol. $7,39-52$

27. CNPT 2001. Alto Juruá Extractive Reserve Population Census Unpublished Report.

2. Peralta, P. and Mather, P. 2000. An analysis of deforestation patterns in the extractive reserves of Acre, Amazonia from satellite imagery: a landscape ecological approach. Int. J. Remote Sensing 21, 2555-2570.

29. Almeida, M.W.B. 1993. The Making of a Forest Peasantry: The Rubber Tappers of the Upper Jurua River. PhD Thesis, Cambridge University, UK.

30. Instituto Brasileiro de Geografia e Estadística 2002. Censo Demográfico 1991 and Censo Demográfico 2000: Resultados do Universo. (http://www.ibge.gov.br)

31. Redford, K.H. 1992. The empty forest. BioScience 42, 412-422.

32. Carneiro da Cunha, M. and Almeida, M.B. (eds.). 2002. Forest Encyclopaedia. Alto Juruá: People's knowledge and practices (In Portuguese). Compañía deas Letras, São Paulo, Brazil, $735 \mathrm{pp}$

33. Brown, K. and Rosendo, S. 2000. Environmentalists, rubber tappers and empowerment: the politics and economics of extractive reserves. Dev. Change 31, 201-227.

34. Boeke, J.H. 1953. Economics and Economic Policy of Dual Societies. Institute of Pacific Relations, NY, $324 \mathrm{pp}$

35. In fact, the size of herd modal class is two cows, and two-thirds of cattle owners have fewer than six cows.

36. Vegetal leather is made of sheets of cotton impregnated in rubber that is then smoked to produce a waterproof, leather-like material sold in fashion shops in Brazil and in some European countries

37. Some elderly people played a major role in the establishment of AJER and the preparation of its management plan. Moreover, they have also acted as Fiscais Ambientais ("environmental attorneys") to check the enforcement of the plan and to mediate in case of disputes, thus contributing de facto to the conservation of AJER.

38. Bakú, K. 1988. From proletarian to peasant: rural transformation in the state of Acre, 1870-1986. J. Dev. Stud. 24, 141-160.

39. Fearnside, P. 2003. Conservation policy in Brazilian Amazonia: understanding the dilemmas. World Dev. 31, 757-779.

40. Kainer, K.K., Schmink, M., Pinheiro Leite, A.C. and da Silva Farell, M.J. 2003 Experiments in forest-based development in Western Amazonia. Soc. Nat. Res. 16, 869 886

41. First submitted 15 Dec. 2003. Revised manuscript received 26 April 2004. Accepted for publication 4 May 2004.

Manuel Ruiz-Pérez is associate professor at the Autonomous University of Madrid, Madrid, Spain, and research associate at the Center for International Forestry Research in Bogor, Indonesia. His address: Dpt. Ecologia-Facultad Ciencias, Universidad Autonoma de Madrid, 28049-Madrid, Spain. manuel.ruiz@uam.es

Mauro Almeida is a professor at Campinas State University, São Paulo, Brazil. malmeida@unicamp.br

Sonya Dewi is a scientist at the Center for International Forestry Research, Bogor, Indonesia. s.dewi@cgiar.org

Eliza Mara Lozano Costa is a doctoral student. eliza@obelix.unicamp.br

Mariana Ciavatta Pantoja is a consultant. maripantoja@uol.com.br

Atie Puntodewo is a scientist at the Center for International Forestry Research, Bogor, Indonesia. a.puntodewo@cgiar.org

Augusto de Arruda Postigo is a doctoral student. augustopostigo@ hotmail.com

Alexandre Goulart de Andrade is an associate researcher at the Vidágua Environmental Institute. alexgoulart@uol.com.br 